OPEN ACCESS

Edited by:

Anna Karolina Kiss, Medical University of Warsaw, Poland

Reviewed by: Diwakar Bastihalli Tukaramrao, The Pennsylvania State University, United States

Egeria Scoditti,

Italian National Research Council, Italy

*Correspondence:

Rainer de Martin

rainer.demartin@meduniwien.ac.at

Specialty section:

This article was submitted to

Ethnopharmacology,

a section of the journal

Frontiers in Pharmacology

Received: 26 October 2021 Accepted: 22 December 2021

Published: 18 January 2022

Citation:

Natalia P, Zwirchmayr J, Rudžionytè I, Pulsinger A, Breuss JM, Uhrin P, Rollinger JM and de Martin $R$ (2022) Pterocarpus santalinus Selectively Inhibits a Subset of Pro-Inflammatory Genes in Interleukin-1 Stimulated Endothelial Cells.

Front. Pharmacol. 12:802153. doi: 10.3389/fphar.2021.802153

\section{Pterocarpus santalinus Selectively Inhibits a Subset of Pro-Inflammatory Genes in Interleukin-1 Stimulated Endothelial Cells}

\author{
Priscilla Natalia ${ }^{1}$, Julia Zwirchmayr ${ }^{2}$, leva Rudžionytė ${ }^{1}$, Alexandra Pulsinger ${ }^{1}$, \\ Johannes M. Breuss ${ }^{1}$, Pavel Uhrin ${ }^{1}$, Judith M. Rollinger ${ }^{2}$ and Rainer de Martin ${ }^{1 *}$ \\ ${ }^{1}$ Department of Vascular Biology and Thrombosis Research, Medical University of Vienna, Vienna, Austria, ${ }^{2}$ Department of \\ Pharmaceutical Sciences, Division of Pharmacognosy, Faculty of Life Sciences, University of Vienna, Vienna, Austria
}

Based on the traditional use and scientific reports on the anti-inflammatory potential of red sandalwood, i.e., the heartwood of Pterocarpus santalinus L., we investigated its activity in a model of IL-1 stimulated endothelial cells. Endothelial cells were stimulated with IL-1 with or without prior incubation with a defined sandalwoodextract (PS), and analyzed for the expression of selected pro-inflammatory genes. The activity of NF-kB, a transcription factor of central importance for inflammatory gene expression was assessed by reporter gene analysis, Western blotting of $I_{\kappa} \mathrm{B} \alpha$, and nuclear translocation studies. In addition, microarray studies were performed followed by verification of selected genes by QPCR and supplemented by bioinformatics analysis. Our results show that PS is able to suppress the induction of E-selectin and VCAM-1, molecules that mediate key steps in the adhesion of leukocytes to the endothelium. It also suppressed the activity of an $\mathrm{NF}-\kappa \mathrm{B}$ reporter, I $\mathrm{\kappa B} \alpha$ phosphorylation and degradation, and the nuclear translocation of NF- $\kappa B$ RelA. In contrast, it stimulated JNK phosphorylation indicating the activation of the JNK signaling pathway. Gene expression profiling revealed that PS inhibits only a specific subset of $\mathrm{IL}-1$ induced genes, while others remain unaffected. Most strongly suppressed genes were the signal transducer TRAF1 and the chemokine CX3CL1, whereas IL-8 was an example of a non-affected gene. Notably, PS also stimulated the expression of certain genes, including ones with negative regulatory function, e.g., members of the NR4A family, the mRNA destabilizing protein TTP as well as the transcription factors ATF3 and BHLHB40. These results provide mechanistic insight into the anti-inflammatory activity of PS, and suggest that it acts through the interplay of negative and positive regulators to achieve a differential inhibition of inflammatory gene expression.

Keywords: Pterocarpus santalinus, red sandal wood, inflammation, endothelial cells, E-selectin, TRAF1, NF-kappa B, CX3CL1 


\section{INTRODUCTION}

Pterocarpus santalinus L. (Fabaceae) grows as a small tree throughout the tropical regions, especially South-East Asia (Arunakumara et al., 2011), and has been used as an ancient Indian as well as traditional Chinese and European remedy (Navada and Vittal, 2014). Medical applications included the treatment of diverse diseases and conditions such as inflammation, diabetes, skin diseases, headache, jaundice, and wound healing; also gastro- and hepatoprotective, anti-microbial, and hypo-lipidemic effects have been reported (Bulle et al., 2016b; Dahat et al., 2021).

Anti-inflammatory properties of $P$. santalinus extracts and some of its isolated metabolites have been demonstrated in several model systems including, e.g., carrageenan-induced paw edema, TNFa production in lipopolysaccharide-stimulated RAW264 cells, concanavalin A stimulated T cell proliferation, and superoxide anion generation in neutrophils (Cho et al., 2001; Kumar, 2011; Yu et al., 2011).

Inflammation is a common feature of many diseases that can affect almost any tissue and organ; prominent examples include the skin, the gastrointestinal tract, the joints, the liver, and the central nervous and cardiovascular systems (Chen et al., 2018). It involves many different cell types and chemical mediators, however, one common denominator is that immune cells need to exit from the blood vessels into the underlying tissue to fulfill their function. Crossing the endothelial monolayer requires endothelial cells (EC) to express, in response to inflammatory stimulation chemokines, cell adhesion molecules, and others to enable and control this process (Mayer et al., 2004). For this reason pro-inflammatory gene expression has proven highly effective as a primary model to monitor pro- and antiinflammatory activities, which are to a large extent regulated by the transcription factor NF- $\mathrm{B}$. NF- $\kappa \mathrm{B}$ represents a family of five members, RelA/p65, RelB, c-Rel, $\mathrm{NFkB} 1 / \mathrm{p} 50$, and $\mathrm{NFkB} 2 / \mathrm{p} 52$ that form homo- and heterodimers. In EC, the predominant form is the RelA/ p50 heterodimer. It is activated in response to e.g., IL-1, TNF, LPS, advanced glycation end products, or oxidized lipids through cytoplasmic-to-nuclear translocation of the pre-formed protein after release from its inhibitor IкBa. A key step in the NF- $\kappa \mathrm{B}$ signaling pathway is the phosphorylation and ubiquitination-dependent degradation of its inhibitor I $\mathrm{B} \mathrm{B}$, thereby enabling the cytoplasmic transcription factor to translocate to the nucleus (De Martin et al., 2000; Mussbacher et al., 2019).

Based on previous reports on anti-inflammatory activities of PS and preliminary results from our lab we aimed to substantiate this activity in our model system of IL-1 stimulated EC and to provide a more detailed insight into its mode of action on the molecular level. We hypothesize that PS, which constitutes a complex mixture of potentially bioactive compounds may exert specific effects on certain parts of the inflammatory response, a feature that could be desirable for clinical applications.

\section{MATERIALS AND METHODS}

\section{Preparation and Characterization of the Heartwood Extract}

The heartwood of $P$. santalinus was obtained from Kottas Pharma GmbH, Vienna, Austria (Ch.Nr.: P16301836). A voucher specimen (JR-20190315-A1) is deposited at the Department of Pharmaceutical Sciences, Division of Pharmacognosy, University of Vienna, Austria. A large-scale extract was prepared according to the protocol for the generation of lead-like enhanced (LLE) extracts as previously described in Kratz et al. (2016), adapted from Camp et al. (2012). Briefly, $1 \mathrm{~kg}$ of the dried, pulverized heartwood was defatted with $2 \mathrm{~L}$ n-hexane (VWR International, Radnor, PA, United States; AnalaR NORMAPUR ACS, $\geq 95 \%$ ) for 3 days on a nutator. The obtained $n$-hexane extract was discarded and the remaining defatted material was extracted with $4 \mathrm{~L}$ dichloromethane $\left(\mathrm{CH}_{2} \mathrm{Cl}_{2}\right)$; VWR International; GPR RECTAPUR, $\geq 99 \%$ ) for 3 days on a shaker. The $\mathrm{CH}_{2} \mathrm{Cl}_{2}$ extract was filtered, and the filtrate evaporated on a rotary evaporator. The remaining plant material was extracted two more times with $\mathrm{CH}_{2} \mathrm{Cl}_{2}$. The same procedure was repeated three times with methanol $(\mathrm{MeOH}) . \mathrm{CH}_{2} \mathrm{Cl}_{2}$ and $\mathrm{MeOH}$ extracts were combined and dried under vacuum to obtain $124.44 \mathrm{~g}$ of the LLE, i.e., PS. The dried extract (PS) was dissolved in DMSO (Carl Roth; Rotipuran $\geq 99.8 \%$, p.a.) to a final concentration of $10 \mathrm{mg}$ / $\mathrm{ml}$ and stored at $-20^{\circ} \mathrm{C}$ until used. Characterization and dereplication of the extract was done by UPLC-ESI-MS (see Supplementary Figure S1 and Supplementary Table S1).

\section{Cell Culture}

Human umbilical vein endothelial cells (HUVEC) were isolated from umbilical cords using collagenase treatment essentially as described (Jaffe et al., 1973; Zhang et al., 1997). The studies were reviewed and approved by Ethics Commission of the Medical University of Vienna. Written informed consent was provided by the participants' legal next of kin. Cells were seeded in $75 \mathrm{~cm}^{2}$ flasks coated with $1 \%$ gelatin (Sigma, St. Louis, MO, United States, \#04055) and cultured in M199 medium (Lonza, Basel, Switzerland, \#12-119F) with 20\% heat-inactivated FBS (Sigma, St. Louis, MO, United States, \#F6765), penicillin (100 units/ml), streptomycin $(100 \mu \mathrm{g} / \mathrm{ml})$, (Pen-Strep, Lonza, Basel, Switzerland, \#DE17-602E), 2 mM L-glutamine (Sigma; \#G7513), 5 units/ml heparin, and $25 \mu \mathrm{g} / \mathrm{ml}$ ECGS (Promocell, Heidelberg, Germany, ECGS/Heparin \#C-30140). Cells were passaged at a ratio of 1:3 and used until passage 5 for experiments.

\section{Antibodies and Reagents}

Recombinant human IL-1 $\beta$ was from R\&D Systems, Minneapolis, MN, United States (\#201-LB). The TAK1 inhibitor (5Z)-7-oxozeaenol: (8-(5-chloro-2-(4methylpiperazin-1-yl) isonicotinamido)-1-(4-fluorophenyl)-4,5dihydro-1H-benzo [g] indazole-3-carboxamide was from Sigma (\#499610) and used at a final conc of $5 \mu \mathrm{M}$. The following antibodies were used: NF- $\kappa B$ p65 (Santa Cruz \#sc-372), IкBa (Cell Signaling, Frankfurt, Germany, \#9241; 1:1000), phosphoIкBa (Cell Signaling, \#2859), and $\beta$-actin (Santa Cruz, Heidelberg, 


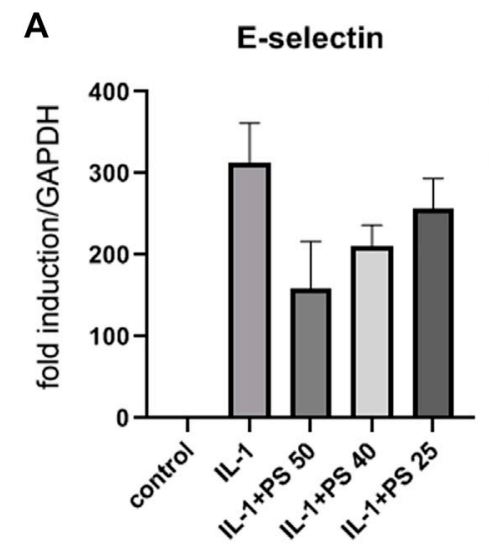

B

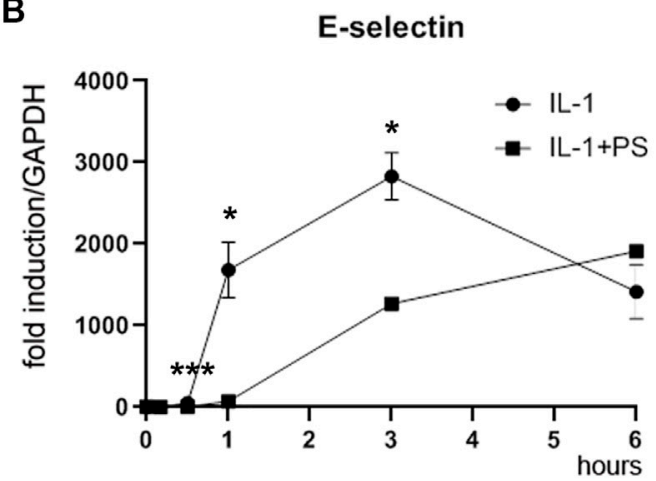

VCAM-1
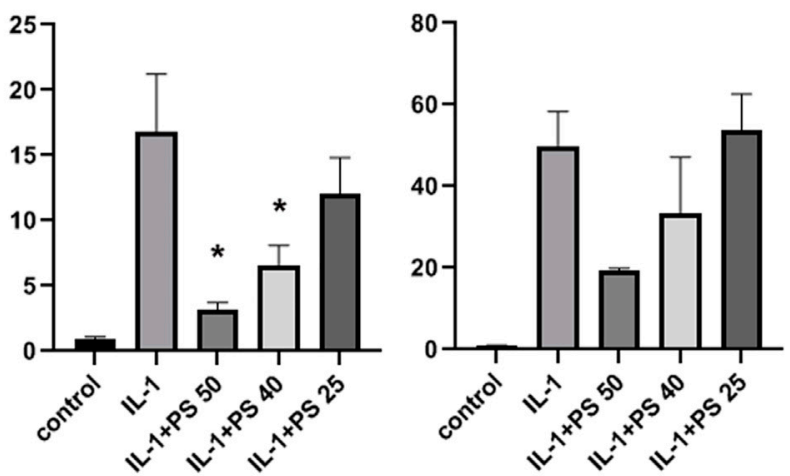

VCAM-1

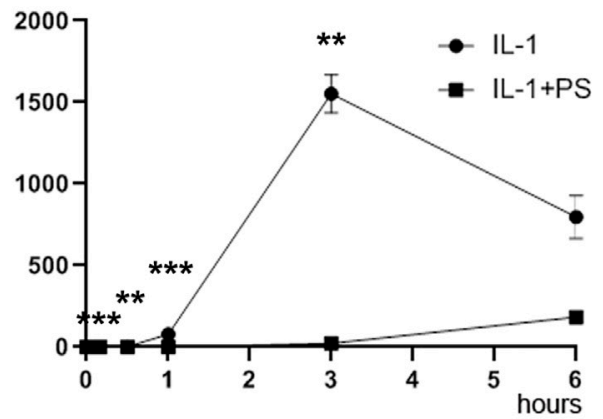

IL-8

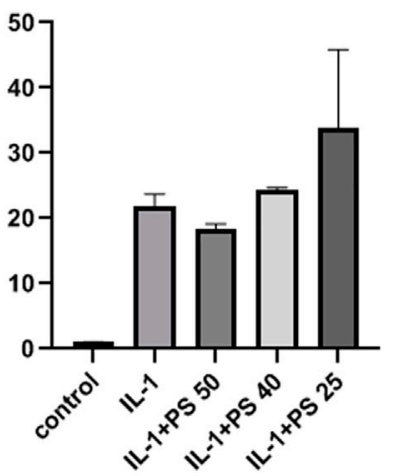

C

CSF2

D
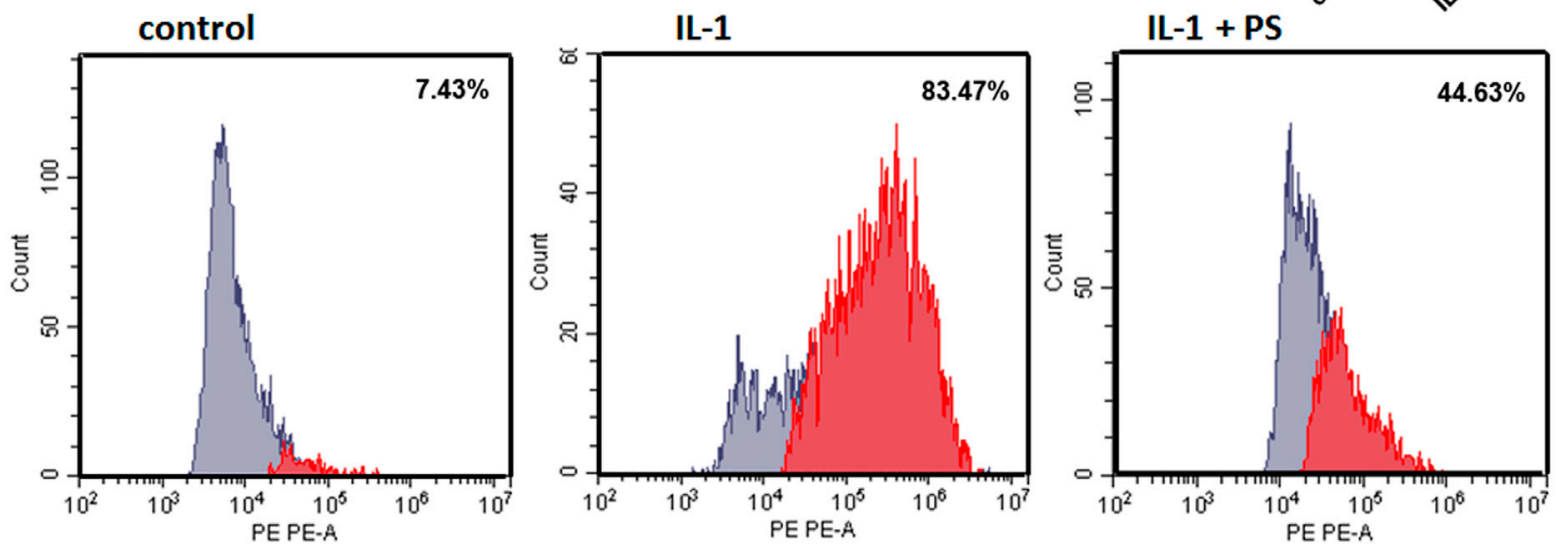

FIGURE 1 |PS suppresses the expression of E-selectin, VCAM-1, A20, and CSF2, but not IL-8. (A) HUVEC were pre-incubated for 30 min with 50 , 40 , and 25 4 / $\mathrm{ml} \mathrm{PS}$, then stimulated with $5 \mathrm{ng} / \mathrm{ml} \mathrm{IL-1}$ for $2 \mathrm{~h}$ and analyzed for E-selectin, VCAM-1, A20, and IL-8 mRNA by qPCR. Relative mRNA levels were normalized to GAPDH and expression levels are depicted as mean fold change +/- SD as compared to unstimulated control cells. (B) HUVEC were pretreated with 50 $\mu$ g/ml PS, then

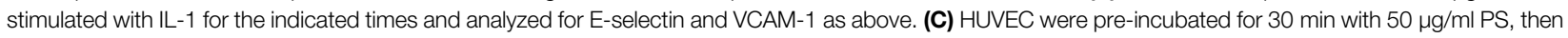
stimulated with $5 \mathrm{ng} / \mathrm{ml} \mathrm{IL-1}$ for $3 \mathrm{~h}$, and supernatants analyzed for CSF2 by ELISA. (D) HUVEC were stimulated with $5 \mathrm{ng} / \mathrm{ml} \mathrm{IL}-1$ either alone for $3 \mathrm{~h}$ or after pretreatment for $30 \mathrm{~min}$ with $50 \mathrm{\mu g} / \mathrm{ml}$ PS, stained with PE-labelled anti-VCAM-1 antibody and analyzed by FACS. Percentages of VCAM-1 positive cells are given in the inserts. ${ }^{\star},{ }^{\star \star}$, and ${ }^{* \star *}$ indicate $p<0.05,0.01$, and 0.001 , respectively, of IL-1 + PS versus IL-1 alone. Note that relative levels of induction may vary between different experiments.

Germany, \#sc-1616). As secondary antibodies, goat anti-mouse HRP (Invitrogen, Carlsbad, CA, United States, \#31432), donkey anti-rabbit IgG HRP-linked whole antibody (Sigma, \#GENA934), and goat anti-rabbit IgG conjugates with Alexa Fluor 488 (Invitrogen, \#A32723) were used.

\section{Cytotoxicity Assay}

HUVEC were incubated with the indicated concentrations of PS for $6 \mathrm{~h}$, and the toxicity assayed using the Resazorin-based in vitro Toxicology Assay Kit (Tox8; Merck, Darmstadt, Germany) according to the manufacturer's recommendations. 


\section{Quantitative Real-Time PCR}

Total RNA was isolated from HUVEC using the PeqGold Total RNA Isolation Kit (VWR International, Radnor, United States, \#732-2868) according to the manufacturer's recommendations. $1 \mu \mathrm{g}$ RNA was reverse-transcribed using random hexamers (Fisher Scientific, Schwerte, Germany; \#SO142) and murine leukemia virus reverse transcriptase (Fisher Scientific, \#10338842). Primers were designed using the software "Primer3," and sequences given in Supplementary Table S2. qPCR was performed using the SsoAdvanced Universal SYBR Green Supermix (BioRad, Vienna, Austria, \#1725272) in a StepOnePlus real-time therocycler (Applied Biosystems, Foster City, CA, United States). Relative mRNA expression was normalized to GAPDH. Triplicate samples were analyzed except for Figure 1A where duplicates were performed. Fold changes in mRNA expression were calculated according to the 2$\Delta \Delta$ Ct method (Livak and Schmittgen, 2001).

\section{FACS Analysis}

HUVEC were grown to post-confluency in 6-well plates, pretreated for $30 \mathrm{~min}$ with $50 \mu \mathrm{g} / \mathrm{ml}$ PS or left untreated, then stimulated with $5 \mathrm{ng} / \mathrm{ml} \mathrm{IL-1} \beta$ for $3 \mathrm{~h}$. Cells were harvested by trypsinization, stained with anti-VCAM1 antibody (anti-CD106PE, \#305806, Biozym Scientific GmbH, Vienna, Austria) according to the recommendation of the manufacturer, fixed with paraformaldehyde and analyzed on a Cytoflex S (Beckman Coulter, Brea, CA, United States) instrument.

\section{Western Blotting}

HUVEC grown to post-confluency in 6-well plates. Following pre-incubation for $30 \mathrm{~min}$ with $50 \mu \mathrm{g} / \mathrm{ml}$ PS, they were stimulated with IL-1 $\beta(5 \mathrm{ng} / \mathrm{ml})$ for the periods of time indicated in the Figures. Cells were lysed in Laemmli buffer, and Western analysis for I $\mathrm{I} B \alpha$ and $\mathrm{p}$ I $\kappa \mathrm{B} \alpha$, as well as $\beta$-actin, was performed as described using 10\% SDS-PAGE (Seigner et al., 2018). For reprobing, membranes were stripped in $60 \mathrm{mM}$ Tris $\mathrm{pH}=7.0 / 2 \%$ $\mathrm{SDS} / 0.7 \% \beta$-mecaptoethanol for $10 \mathrm{~min}$ at $50^{\circ} \mathrm{C}$. Densitometric analysis was done with ImageJ.

\section{Transfection and Reporter Gene Assays}

HUVEC in the exponential growth phase were trypsinized and transfected by electroporation using a BioRad Gene Pulser with the settings $200 \mathrm{~V} / 960 \mu \mathrm{F} .2 \times 10^{6}$ cells were electroporated in $400 \mu \mathrm{l} \mathrm{RPMI}$ medium in $0.4 \mathrm{~cm}$ cuvettes with a total of $10 \mu \mathrm{g}$ plasmid DNA. Plasmids were pNL3.2.NF- $\kappa$ B-RE (Promega, Madison, WI, United States) and pmaxGFP (Amaxa/Origene, Rockville, MD, United States). Cells were seeded into 6-well plates and grown for 2 days before stimulation. Luciferase levels were analyzed using the NanoGlo Luciferase Assay (Promega, \#N1110) according to the manufacturer's instructions and normalized to EGFP fluorescence.

\section{Enzyme-Linked Immonosorbent Assay}

Levels of CSF2 (GM-CSF) were determined by ELISA (ELISA MAX Deluxe Set Human GM-CSF, \#B432004, Biozyme Scientific $\mathrm{GmBH}$, Hessisch Oldendorf, Germany) from supernatants of
HUVEC pre-treated with $50 \mu \mathrm{M}$ PS for $30 \mathrm{~min}$ and stimulated with $5 \mathrm{ng} / \mathrm{ml}$ IL1 for $3 \mathrm{~h}$ as indicated in Figure 1C.

\section{Microarray and Bioinformatic Analysis}

Total RNA was isolated using the RNeasy Plus Micro Kit (Qiagen, Hilden, Germany) including DNAse digestion. Analysis was done by the Core Facilities of the Medical University of Vienna. Labelling was performed with the WT Plus Labeling Kit (\#902280, ThermoFisher, Waltham, MA, United States), and probes hybridized to Human Gene 2.0 ST Arrays (\#902113, ThermoFisher). Data were deposited in the GEO database (accession no. GSE178106), where additional experimental details are described. Experiments were performed in triplicates, and samples pooled for the microarray analysis. The heat map was generated using Genesis software (Institute of Genetics and Bioinformatics, Graz University of Technology). Transcription factor motif analysis was performed using NetworkAnalyst 3.0 (https://www.networkanalyst.ca) with the Encode database. PS responsive genes (Figure 4A and Supplementary Table S3) that were induced by IL-1 > 3-fold and down-regulated by PS $>3$-fold were included. The control set consisted of genes with an IL-1 induction > 2-fold and a regulation by PS between 0.9-1.1-fold (Supplementary Table S3).

\section{Statistical Significance Calculations}

Differences between samples were analyzed by ordinary one-way ANOVA using Graph Pad Prism software (San Diego, CA, United States). Dunnett's multiple comparisons test was added for dose-dependency in Figure 1A. *, **, and *** indicate $p<0.05,0.01$, and 0.001 , respectively.

\section{RESULTS}

In previous studies, we have analyzed the anti-inflammatory activity of twenty selected herbal extracts using the reduction of the IL-1 stimulated expression of the cell adhesion molecule E-selectin in human umbilical vein endothelial cells (HUVEC) as readout (Lammel et al., 2020). Here, based on the strength and robustness of its inhibitory action, we have chosen PS for further in-depth analysis. The extract was prepared according to for the generation of lead-like enhanced extracts as described in Materials and Methods, and characterized by UPLC and identification of 6 main compounds (Supplementary Figure S1). No toxicity was observed at a concentration of $50 \mu \mathrm{g} / \mathrm{ml}$ (Supplementary Figure S2), so the subsequent experiments were performed at this or lower concentrations. PS tested at 50,40 and $25 \mu \mathrm{g} / \mathrm{ml}$ decreased the IL-1 induced expression of the mRNAs of E-selectin and another cell adhesion molecule, VCAM-1, as well as the inhibitor of apoptosis A20 in a dose-dependent manner. However, IL-8, a prominent cytokine in the inflammatory process was, apart from a slight decrease at $50 \mu \mathrm{g} / \mathrm{ml}$ PS, not significantly affected (Figure 1A). A kinetic analysis showed that mRNA levels of both cell adhesion molecules were suppressed by the PS extract, with highest effects between 1 and $3 \mathrm{~h}$ post stimulation (Figure 1B). In order to determine the effect of PS on the 
A

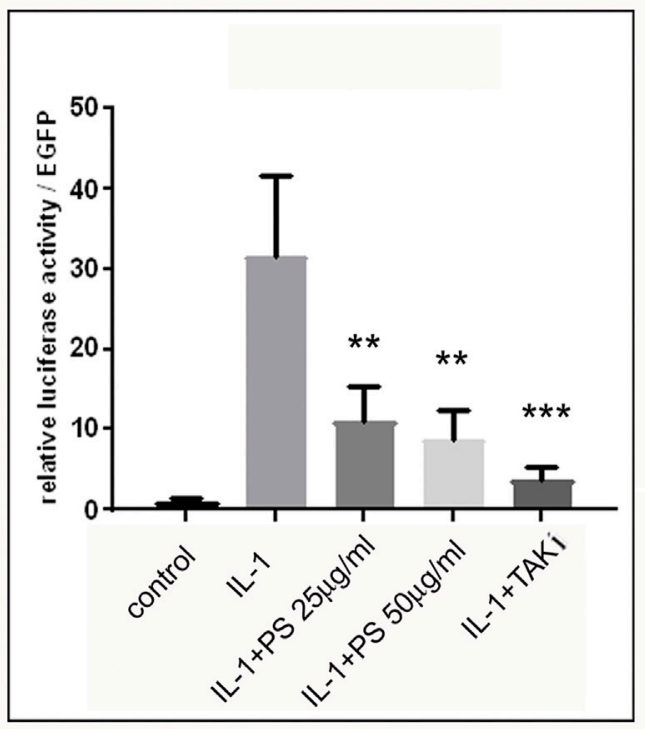

C

IL-1

IL-1 + PS

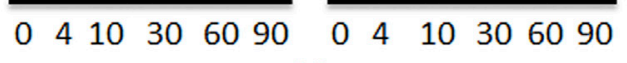

$\mathrm{M}$
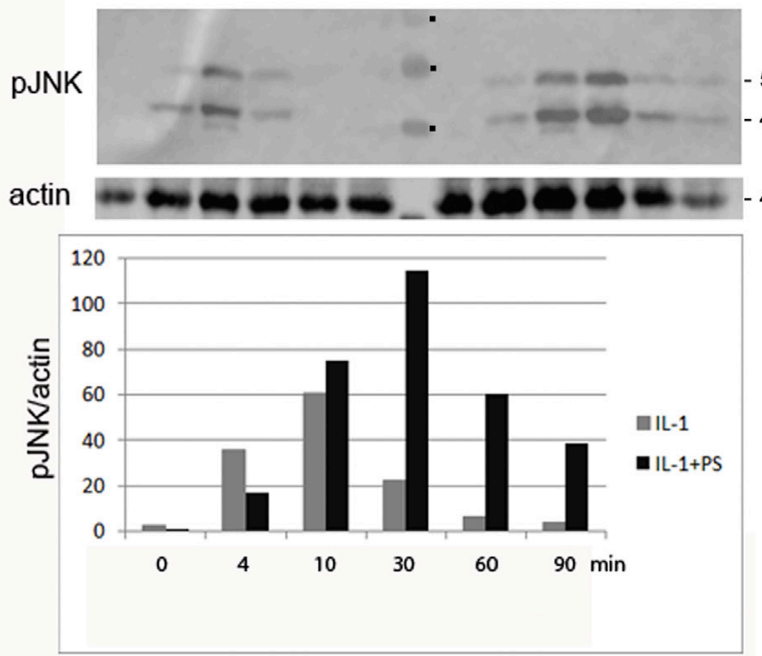

B

$$
\text { IL-1 }
$$

IL-1 + PS

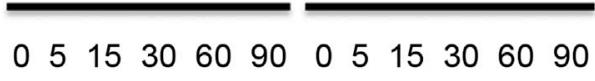

plкB $\alpha$

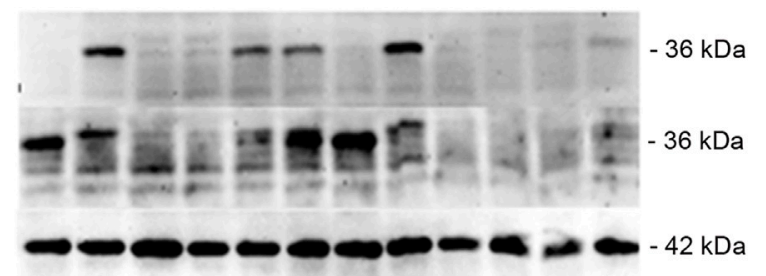

actin

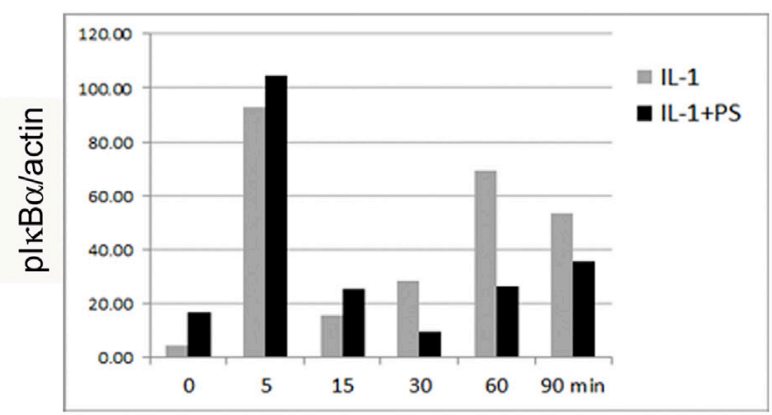

$54 \mathrm{kDa}$ $46 \mathrm{kDa}$

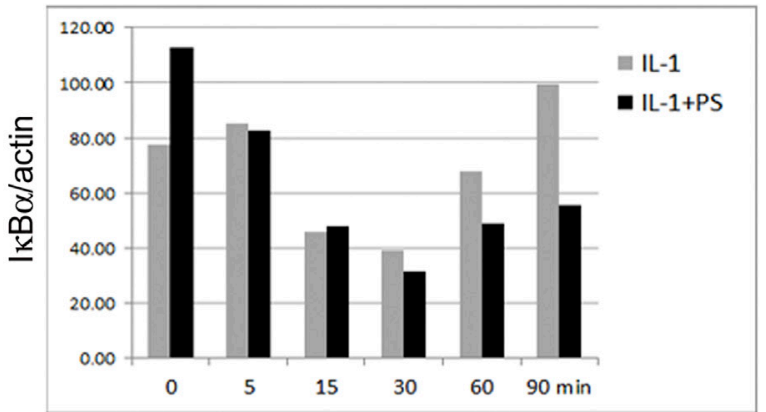

FIGURE 2 |PS inhibits the NF-kB, but enhances the JNK activity. (A) HUVEC were transfected with a NF-kB luciferase reporter construct (NF-kB luc) and EGFP as internal control, pretreated for $30 \mathrm{~min}$ with 25 or $50 \mu \mathrm{g} / \mathrm{ml} \mathrm{PS}$ or $5 \mu \mathrm{M}$ TAK1 inhibitor (TAKi) as positive control and stimulated with $5 \mathrm{ng} / \mathrm{ml}$ IL-1. Control: unstimulated cells. Luciferase levels were determined after $16 \mathrm{~h}$ and are shown as relative luciferase levels normalized to EGFP. Triplicate samples were analyzed. ${ }^{* \star} p<0.01$, ${ }^{* \star \star} p<$ 0.001 as compared to IL-1 stimulation; (B) HUVEC were either treated with $5 \mathrm{ng} / \mathrm{ml} \mathrm{IL-1}$ alone (left) or pre-incubated with $50 \mu \mathrm{gg} / \mathrm{ml} \mathrm{PS} \mathrm{for} 30 \mathrm{~min}$ following stimulation with $\mathrm{LL}-1$ (right) for the indicated times and analyzed for phospho- $\mathrm{I} \mathrm{KB} a, \mathrm{I} \mathrm{KB} a$, and $\beta$-actin by Western blotting. Approximate $\mathrm{MWs}$ of the proteins are given on the right. A quantification is given below. (C) Western analysis of HUVEC treated with $50 \mu \mathrm{g} / \mathrm{ml} \mathrm{PS} \mathrm{for} 30 \mathrm{~min}$ followed by stimulation with $5 \mathrm{ng} / \mathrm{ml} \mathrm{IL-1} \mathrm{for} \mathrm{the} \mathrm{indicated}$ times in minutes. Samples were analyzed for phospho-JNK (pJNK) and $\beta$-actin. The approximate MW of the two pJNK bands are indicated on the right. M: marker, the three visible bands of 40, 55 and $70 \mathrm{kDA}$ are indicated by dots. Lower panel: quantification of pJNK (average of the p46 and p54 bands) normalized to $\beta$-actin.

levels of selected proteins we performed an ELISA for a soluble factor, CSF2 (Figure 1C), one of the top PS-regulated genes in the microarray analysis (see below), and a FACS analysis of a membrane-stemming molecule, VCAM-1 (Figure 1D). Both analyses confirmed the suppressive effect. Moreover, during the initial characterization of the extract, E-selectin protein levels have been assayed by cell ELISA and found to be downregulated by PS (Lammel et al., 2020).

Since NF- $\mathrm{kB}$ is a main regulator of pro-inflammatory genes in $\mathrm{EC}$ we assayed its activity using reporter gene analysis. A NF- $\mathrm{kB}$ 
minimal promoter-luciferase reporter was transfected into HUVEC followed by stimulation with combinations of IL-1 and PS. As shown in Figure 2A, PS inhibited the IL-1 induced activity of the reporter gene in a dose-dependent manner, however, not to the same extent as an inhibitor of TAK1, a mitogen-activated protein 3 (MAP3) type kinase in the NF- $\kappa \mathrm{B}$ signaling pathway that we used as positive control. Furthermore, we analyzed the kinetics of I $\mathrm{B} \alpha$ phosphorylation and degradation using Western blotting. Following IL-1 stimulation, I $\kappa \mathrm{Ba}$ was phosphorylated within $5 \mathrm{~min}$, then degraded to undetectable levels, and re-synthesized after $60 \mathrm{~min}$ as demonstrated by staining with anti-pIкBa and antitotal I $\mathrm{\kappa Ba}$ antibodies (Figure 2B, first and second panel, respectively). This is in accordance with previous studies indicating a second wave of activation approximately $1 \mathrm{~h}$ after stimulation (Hoffmann et al., 2002; Winsauer and de Martin, 2007). However, in the early phase of IL-1 stimulation, no differences between control- and PS-treated samples were observed. Pre-treatment with PS alone for $30 \mathrm{~min}$ even caused a small increase in I $\mathrm{B} \alpha$ levels. This might be due to an initial stress response of the extract [as also supported by the increased levels of pJNK (Figure 2C)]. Given the complex composition of herbal extracts it appears feasible that both positive and negative factors may contribute to a biological effect where, depending on the time of incubation, the one or the other could prevail. In contrast, PS largely prevented the second wave of I $\mathrm{BB} \alpha$ resynthesis and phosphorylation as seen at 60 and $90 \mathrm{~min}$. This indicates that PS acts in part by interfering with the later phase of NF- $\kappa \mathrm{B}$ signaling at a point of the pathway at or above the level of $\mathrm{I} \kappa \mathrm{Ba}$. However, another signaling pathway known to be activated during the inflammatory response, JNK (Kaminska, 2005), was found to be stimulated, as shown by the enhanced and prolonged phosphorylation of JNK (Figure 2C).

Encouraged by our initial finding of a differential effect of PS towards pro-inflammatory gene expression (i.e., E-selectin and VCAM-1 versus e.g., IL-8, one of the most prominent and abundant genes in EC), we aimed to obtain a comprehensive overview over the effect(s) of PS. Therefore, expression profiling was performed comparing 1) unstimulated cells (i.e., control), 2) IL-1 treated cells, 3) IL-1 plus PS treated cells and 4) PS onlytreated cells. At a threshold of 3-fold stimulation of IL-1 vs. control, 161 genes were up-regulated and 16 down-regulated (lowering the threshold to 2-fold resulted in 362 up- and 201 down-regulated genes), confirming previous studies (Mayer et al., 2004). The >3-fold regulated genes were further sorted by their regulation by PS. Figure 3A shows those genes whose IL-1 response is down-regulated at least 3 -fold by PS (a total of 55 genes), with CX3CL1 and TRAF1 showing strongest inhibition; note that in addition, many genes were downregulated below their basal level by PS alone. In contrast, eight IL-1 stimulated genes were further up-regulated $>3$-fold by PS (Figure 3B). In panel C, 16 genes that were down-regulated by IL1 (>3-fold) are shown, the extent of further regulation (up or down) by PS is indicated by color. Names for the official gene symbols are given in the Supplementary Table S3. Genes that were either highly regulated or could be of special interest for certain biological aspects, e.g., interferon regulatory factor (IRF1)
A

TRAF 1

CX3CL1

NUAK2

VCAM
CSF2

BIRC3

TNFRSF9

PLAU

SERPINB2

TNFAIP

IL1B

IRF1

CSF3

IRAK2

DUSP5

BIRC3

SPRY4

S100A3

KITLG

FOXC2

PPP1R1

BMP2

ICAM1

RNF 198

PPAP2B

LRIG1

SNX5

NFKBID

NOCT

RIPK2

KDM6B

FJX1

PTX3

BCL3

USP 12

LGALSL

HIVEP2

SAMD $4 A$

REL

ZBTB10

EXT1

EHD1

SLC7A2

TNFAIPB

KLF7

NFKB

SOX7

SAV1

CLDN1

MED21

HBEGF

$\mathrm{ZC} 3 \mathrm{H} 12 \mathrm{C}$

ILIA
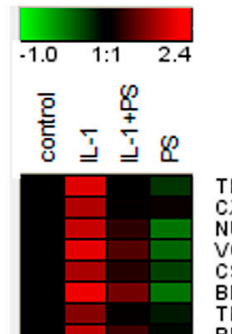

B
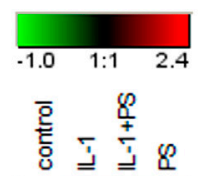

C

ATF3

DDIT4

EGR1
ARRDC3

BHLHE40

ZFP 36

NR4A1
NR4A2
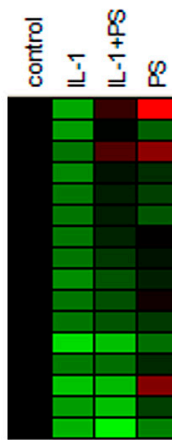

ADM

CLASP2

SPRY1

PABPC4L

CXCL13

AMPD1

C5orf66

HOXA11

HOXA11
MTCP1

ZNF792

ZNF57

C10orf10

TXN

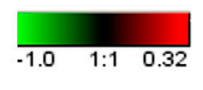

FIGURE 3 | Gene expression profile of PS + IL-1 vs. IL-1 treated HUVEC. A heat map of genes (Official Gene Symbols; gene names are given in Supplementary Table S3) that are regulated more than 3-fold by PS + IL-1 as compared to IL-1 alone is shown. Cells were pre-treated with $50 \mu \mathrm{g} /$ $\mathrm{ml}$ PS for $30 \mathrm{~min}$ and then stimulated for $2 \mathrm{~h}$ with $5 \mathrm{ng} / \mathrm{ml} \mathrm{IL-1.} \mathrm{(A)} \mathrm{up-}$ regulation by $\mathrm{IL}-1$, down-regulation by $\mathrm{PS}$; (B) up-regulation by $\mathrm{IL}-1$ and further up by PS; (C) down-regulation by IL-1, further regulation by PS (up or down). Colors indicate up-regulation (red) and down-regulation (green), logarithmic scale. Note that the scale was adjusted between (A), (B), and (C) for optimal visualization.

and plasminogen activator (PLAU) were selected for a more detailed kinetic analysis by $\mathrm{qPCR}$, demonstrating accordance with the results of the microarray experiment (Figure 4).

Besides IL-1, other pro-inflammatory stimuli including TNF or bacterial lipopolysaccharide (LPS) can activate EC to express a similar set of genes. Although binding to different receptors and using in part different receptor-specific adaptors, the respective signaling pathways that lead to $\mathrm{NF}-\kappa \mathrm{B}$ converge at the level of the IKK complex (Mercurio et al., 1997). Thus, assuming that PS acts at least in part though NF- $\kappa$ B inhibition, we investigated whether PS would 


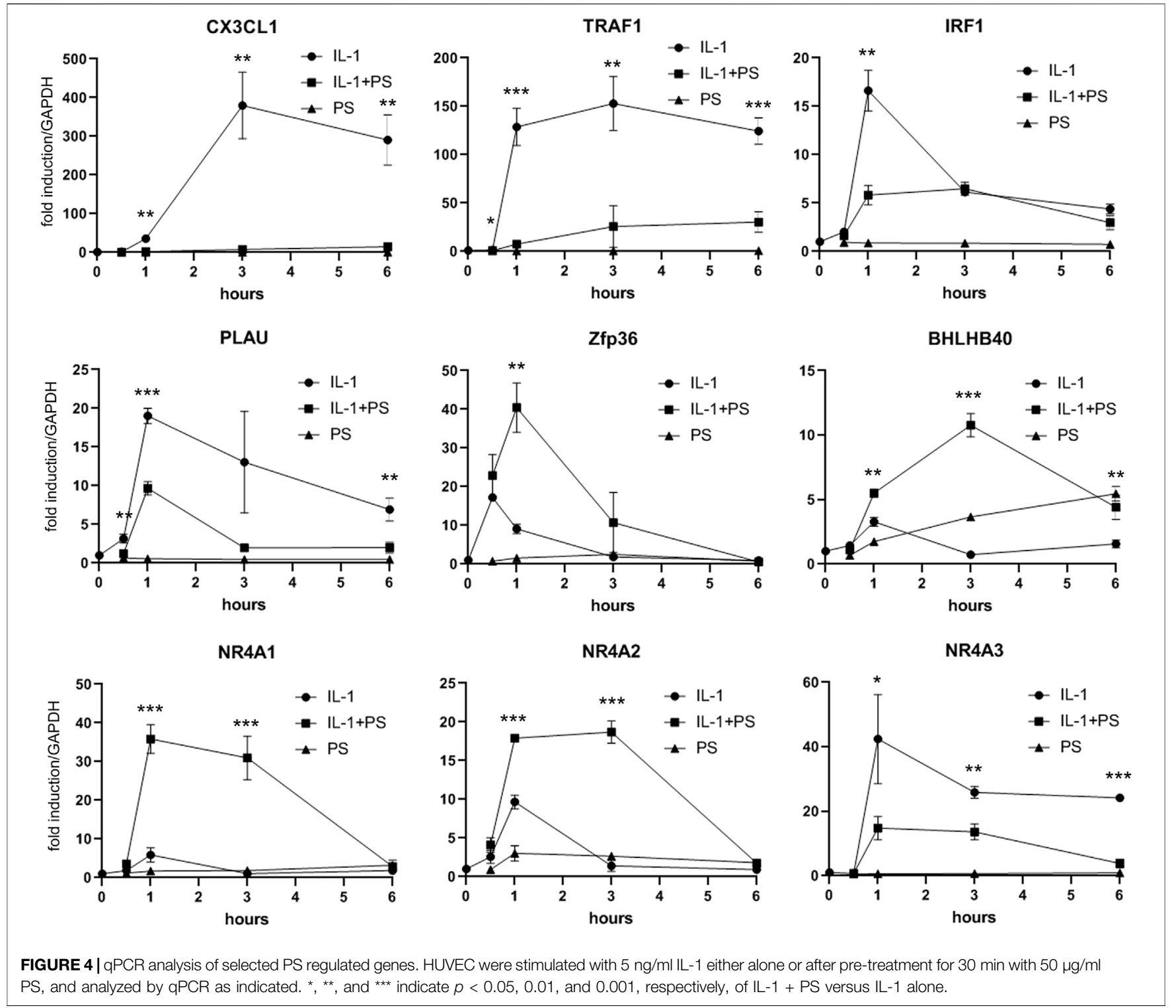

attenuate also TNF- and LPS-stimulated gene expression. As shown in Figure 5, induction of the three genes tested (i.e., CX3CL1, TRAF1, and VCAM-1) was diminished by PS; in the case of LPS, which evokes a slower response as compared to IL-1 and TNF, the inhibition was less pronounced over the observed period.

Given the fact that the IL-1 inducible genes could be grouped into two subsets of PS- responsive and nonresponsive ones, we sought to determine the underlying molecular mechanism(s). As a first working hypothesis, we assumed that at least the vast majority of this differential regulation takes place on the transcriptional level, and analyzed the two subsets in regard to the presence or absence of transcription factor binding sites in their promoter regions. We used Motif search of the NetworkAnalyst software package with the Encode database (see Materials and Methods section); this tool also offers the identification of target gene-micro RNA interactions. As shown in Table 1, the most prominent binding motif was represented by different variations of the NF- $\kappa \mathrm{B}$ site. However, since only a small preference in the subset of PS responsive genes was found (all NF- $\mathrm{KB}$ sequences together account for 0.83 vs. $0.63 \%$ in the control, when normalized for the different numbers of genes in the two sets), this suggests that NF- $\kappa \mathrm{B}$ may only partially account for the observed effects of PS. Two other sites, STAT5A and the target of MIR23 A,B were specifically present in the PS-responsive set. However, only 6 and 7 genes, respectively, contained these sites, suggesting that also these may not be the only ones responsible for the PS effect. Therefore, it can be expected that additional mechanisms affecting different genes are operative. This pluri-mechanistic action is likely to be a result of the interplay from several PS constituents endowed with distinct biological profiles. 


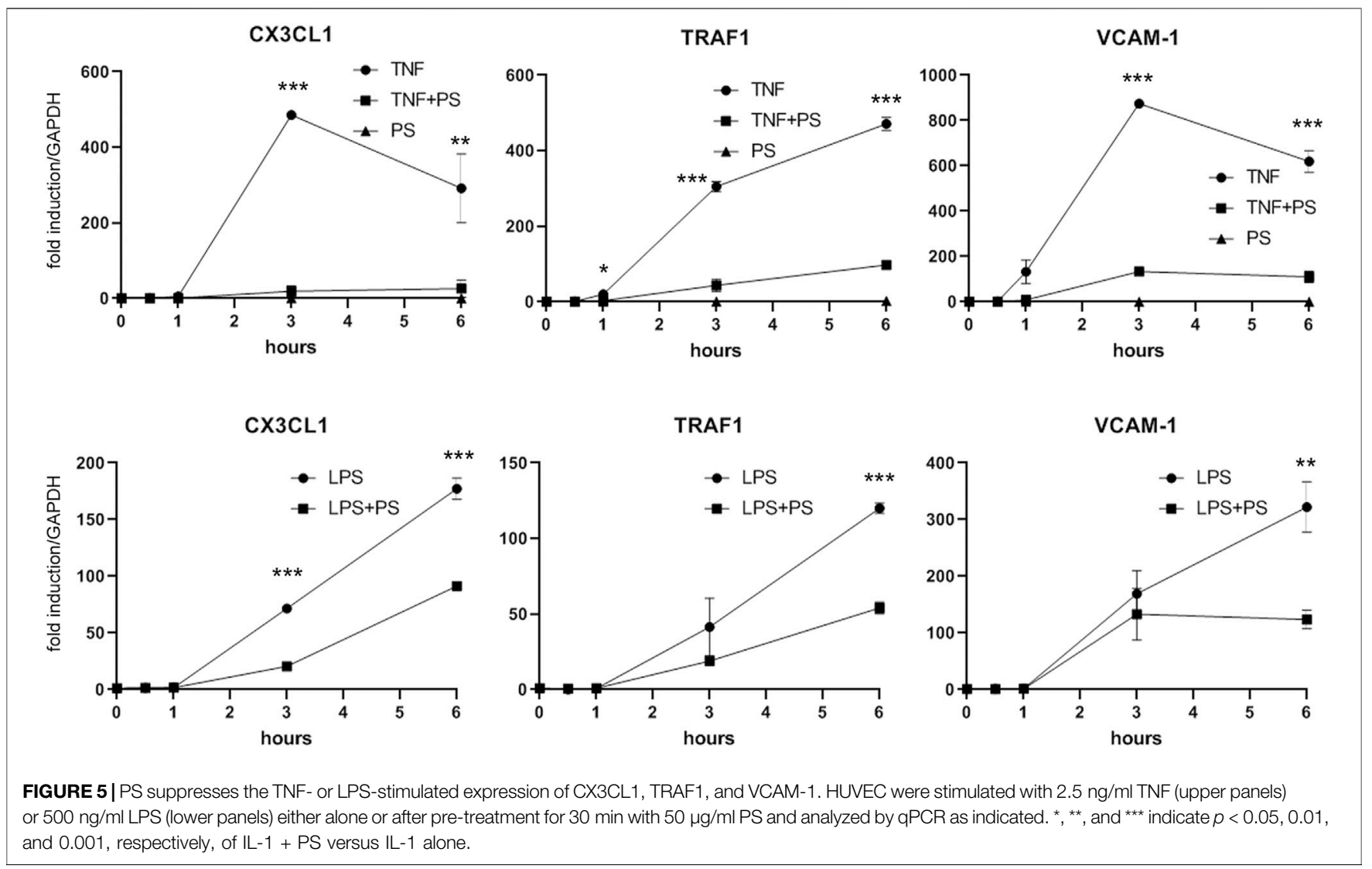

\section{DISCUSSION}

Despite the long-standing traditional use of $P$. santalinus, only few in vivo and in vitro studies on its anti-inflammatory activity, the latter using macrophages, neutrophils, and also T cells, have been performed (Cho et al., 2001; Kumar, 2011; Wu et al., 2011). Despite these studies, the underlying molecular mechanism(s) remain poorly understood. From a pre-characterized set of extracts of herbal and fungal origin, $P$. santalinus has caught our attention due to its strong and robust effect in a model of IL-1 stimulated EC (Lammel et al., 2020). EC play a key role in the inflammatory response due to their control of immune cell transmigration, which requires the tightly regulated expression of cell adhesion molecules, interleukins, and chemotactic factors.

Initially, we assayed IL-1 stimulated E-selectin expression, and found a dose-dependent inhibitory effect of PS on the mRNA level. Inhibition of another adhesion molecule, VCAM-1, was even more pronounced, however, IL-8, an important gene in the inflammatory response, was not affected. A more detailed kinetic analysis of the two adhesion molecules confirmed these findings, as well as the inhibition of VCAM-1 on the protein level (Figure 1).

Since NF- $\kappa \mathrm{B}$ is a prominent regulator of pro-inflammatory genes in EC and has been demonstrated to be a target of many natural products (Kim et al., 2007; Seigner et al., 2019; Lammel et al., 2020), we reasoned that this transcription factor might also be affected by PS. A reporter gene analysis confirmed this hypothesis (Figure 2A), and was further substantiated by $\mathrm{I} \kappa \mathrm{Ba}$ phosphorylation and degradation (Figure 2B). However, PS appeared to display little effects on the early stages of NF- $\mathrm{B}$ activation, whereas I $\kappa \mathrm{B} \alpha$ phosphorylation and degradation were strongly diminished at 60-90 min. This indicates that primarily, the signaling downstream of IкBa degradation was affected by PS, whereas its resynthesis and degradation, which is indicative of a second wave of activation is suppressed. The observation that NF$\kappa \mathrm{B}$ activation occurs in waves has been described by Hoffman and Baltimore in T-cells (Hoffmann et al., 2002) and also by our lab in endothelial cells and fibroblasts (Winsauer et al., 2008; Seigner et al., 2019). Here, preliminary data indicated that nuclear translocation $15 \mathrm{~min}$ after stimulation was not affected (data not shown), suggesting that post-translational modifications of NF- $\kappa \mathrm{B}$ could be targeted by PS. Several modifications that modulate NF- $\kappa B$ activity have been reported and include phosphorylations, acetylations, or S-nitrosylations (Anrather et al., 2005; Perkins, 2006; Sen et al., 2012). Especially the latter can affect redox-sensitive residues, which could be subject to, e.g., polyphenolic compounds with anti-oxidant properties that are present in PS (Bulle et al., 2016a). Alternatively, DNA binding of the transcription factor could be affected, e.g., by IкBa that has been reported to shuttle between nucleus and cytoplasm and prevent DNA binding (Kerr et al., 1991; Birbach et al., 2002). The precise mechanism should be subject to further investigation, preferentially with isolated compounds. We also assayed for 
TABLE 1 | Analysis of potential PS-responsive transcription factors and microRNAs.

\begin{tabular}{|c|c|c|c|c|c|}
\hline Pathway PS & Total & Expected & Hits & $p$-Value & FDR \\
\hline V\$NFKAPPAB_01 & 251 & 0.838 & 9 & 1.19E-07 & 9.91E-05 \\
\hline V\$NFKB_Q6_01 & 232 & 0.774 & 7 & 1.08E-05 & 0.00427 \\
\hline V\$NFKB_Q6 & 254 & 0.848 & 7 & 1.94E-05 & 0.00427 \\
\hline V\$CREL_01 & 256 & 0.854 & 7 & 2.04E-05 & 0.00427 \\
\hline GGGNNTITCC_V\$NFKB_Q6_01 & 134 & 0.447 & 5 & 8.05E-05 & 0.0135 \\
\hline V\$NFKAPPAB65_01 & 237 & 0.791 & 6 & 0.000128 & 0.0179 \\
\hline V\$STAT5A_01 & 251 & 0.838 & 6 & 0.000176 & 0.021 \\
\hline AATGTGA MIR-23A, B & 419 & 1.4 & 7 & 0.000441 & 0.0461 \\
\hline TATAAA_V\$TATA_01 & 1300 & 4.32 & 12 & 0.000871 & 0.0809 \\
\hline V\$NFKB_C & 263 & 0.878 & 5 & 0.00177 & 0.129 \\
\hline V\$GATA_C & 266 & 0.888 & 5 & 0.00186 & 0.129 \\
\hline V\$NFAT_Q4_01 & 266 & 0.888 & 5 & 0.00186 & 0.129 \\
\hline V\$STAT3_01 & 22 & 0.0734 & 2 & 0.00241 & 0.155 \\
\hline Pathway control & Total & Expected & Hits & $p$-Value & FDR \\
\hline V\$CREL_01 & 256 & 0.436 & 5 & 6.11E-05 & 0.034 \\
\hline ACTITAT MIR-142-5P & 288 & 0.491 & 5 & 0.000107 & 0.034 \\
\hline GGGAGGRR_V\$MAZ_Q6 & 2270 & 3.87 & 12 & 0.000122 & 0.034 \\
\hline ACTGCCT MIR-34B & 219 & 0.373 & 4 & 0.000473 & 0.0767 \\
\hline V\$NFKAPPAB65_01 & 237 & 0.404 & 4 & 0.000637 & 0.0767 \\
\hline V\$CHOP_01 & 238 & 0.406 & 4 & 0.000647 & 0.0767 \\
\hline V\$CREBP1_Q2 & 254 & 0.433 & 4 & 0.000826 & 0.0767 \\
\hline V\$NFKB_Q6 & 254 & 0.433 & 4 & 0.000826 & 0.0767 \\
\hline V\$NFKB_C & 263 & 0.448 & 4 & 0.00094 & 0.0767 \\
\hline CAGTATT MIR-200B, C MIR-429 & 469 & 0.799 & 5 & 0.00101 & 0.0767 \\
\hline V\$MYCMAX_B & 268 & 0.457 & 4 & 0.00101 & 0.0767 \\
\hline RNGTGGGC_UNKNOWN & 766 & 1.31 & 6 & 0.00147 & 0.102 \\
\hline CAGGTA_V\$AREB6_01 & 792 & 1.35 & 6 & 0.00174 & 0.112 \\
\hline
\end{tabular}

Among the IL-1 responsive genes a subset of PS responsive (pathway PS), and one of PS non-responsive genes (pathway control) were defined as outlined in Materials and Methods section and shown in the Supplementary Table S3. Their promoter regions were analyzed for transcription factor binding sites and for target gene-microRNA interactions using NetworkAnalyst 3.0.

Sites that are enriched in the PS responsive gene set are indicated in blue, those that are common in both sets in red. Only the top 13 sites (by significance) are shown. FDR, false discovery rate.

activation of another prominent pathway, JNK that is operative during the inflammatory response (Kaminska, 2005). Surprisingly, activation of this pathway was enhanced and prolonged, as shown by Western analysis of phospho-JNK (Figure 2C).

This finding and the initial observation of differential effects on inflammatory gene expression prompted our subsequent analysis of global gene expression in response to PS. When comparing IL-1 treatment of HUVEC with the combination of IL-1 plus PS, striking differences in the susceptibility of IL-1 induced genes towards PS became apparent (Figure 3). For example, levels of the two most strongly affected genes, TRAF1 and CX3CL1, were reduced by 98 and $95 \%$, respectively, by PS, whereas one of the most prominent proinflammatory chemokines in EC, IL-8, remained essentially unchanged, in accordance with Figure 1A. CX3CL1, also known as fractalkine, is an atypical member of the chemokine family. It is a strong chemoattractant for monocytes and T cells, and in its membrane-bound form also for neutrophils (Bazan et al., 1997). TRAF1 is part of the cytoplasmic part of the TNF receptor signaling complex and thus plays a part in TNF signaling by coupling directly to IKK2 (Sughra et al., 2010). As an inducible gene it represents a positive feedback loop for TNF but also LPS signaling (Su et al., 2006; Abdul-Sater et al., 2017); its inhibition by PS would predict to counteract this amplification. However, since also IL-1 and LPS signaling were affected, other mechanisms are likely operative or prevail in this situation. Other induced genes of note include PLAU (urokinase-type plasminogen activator), an important regulator of fibrinolysis, the colony-stimulating factors G-CSF and GM-CSF (CSF2) that serve as differentiation factors for granulocytes and macrophages during the inflammatory episode (Quesenberry and Gimbrone, 1980), BIRC3 (cIAP2), an inhibitor of apoptosis (Guo et al., 2014), and many others. It is noteworthy that at least two genes, TNFAIP2 and A20, the latter also displaying anti-apoptotic properties, have been found to inhibit NF- $\kappa \mathrm{B}$ signaling (Cooper et al., 1996; Thair et al., 2016). Of special interest is IRF1 (interferon-regulatory factor 1), a transcription factor for interferon- $\beta$ (Miyamoto et al., 1988), since it has been demonstrated to cross-talk with NF- $\kappa \mathrm{B}$ upon e.g., VCAM-1 expression, (Neish et al., 1995), and DUSP5, a dual-specificity phosphatase that serves to terminate MAP kinase signaling (Kovanen et al., 2003). Inhibition of its expression could explain the prolonged activation of JNK signaling seen upon PS treatment (Figure 2C).

On the other hand, a number of genes were up-regulated by PS, e.g., the nuclear hormone receptors NR4A1-3 (Rodríguez-Calvo et al., 2017), the transcription factors ATF3 (Jung et al., 2015; Kaitu'U-Lino 
et al., 2017) and Zfp36/TTP (Lai et al., 1999). Cyclooxigenase 2 was also upregulated (approx. 20-fold by IL-1), but only 2-fold more by PS, and therefore does not show up in Figure 2B as the threshold was set to 3-fold regulation by PS. NR4As have been shown to cross-talk with NF-kB and thereby modulate its activity (Murphy and Crean, 2015). For example, NR4A1 (Nurr77) suppressed EC activation though induction of IkBa expression (You et al., 2009). In astrocytes, NF$\mathrm{\kappa B}$ dependent inflammatory activation was inhibited by compensatory expression of NR4A1 and -2 , indicating that they constitute a negative feedback loop (Popichak et al., 2018). NR4A3 over-expression inhibited the NF- $\mathrm{kB}$ signaling in a mouse model of myocardial infarction, by decreasing I $\kappa \mathrm{B} a$ phosphorylation and inhibiting p65 nuclear translocation (Jiang et al., 2019). Lentiviral overexpression of all three factors reduced the expression of proinflammatory cytokines as well as the oxidized low-density lipoprotein uptake in human macrophages (Bonta et al., 2006). ATF3 has been shown to cross-talk to NF- $\kappa B$ and to act as a negative regulator of pro-inflammatory responses in different settings, such as preeclampsia (Kaitu'U-Lino et al., 2017), inflammation after cerebral injury (Wang et al., 2012), and Tolllike receptor 4 signaling (Gilchrist et al., 2006), in the latter case by direct binding to the p65/RelA subunit of NF- $\mathrm{KB}$ (Kwon et al., 2015). Zfp36/TTP, which on one hand binds to AUUUA rich elements in certain mRNAs leading to their destabilization (Lai et al., 1999), can also directly inhibit NF- $\kappa B$ (Schichl et al., 2009). GM-CSF (CSF2) is an example of a mRNA which is destabilized by TTP, suggesting that this could be a mechanism for the down-regulation of this growth factor (Carballo et al., 2000).

Taken together, transcription factors of the NR4A family and ATF3, as well as Zfp36/TTP have been associated at least in some cases with negative regulatory functions either in EC or other cell types, and also to cross-talk with NF- $\kappa$ B. Thus, a number of genes affected by PS have the potential or documented ability to inhibit NF$\kappa \mathrm{B}$ or other functions in EC. However, in general the PS sensitive genes are quite divergent in regard to their function, and this would predict that PS may preferentially inhibit certain aspects of the inflammatory episode, but could also promote others.

For a deeper insight into the mechanism(s) of PS-mediated inhibition we undertook a bioinformatics-based attempt and compared the promoter regions of PS sensitive and non-sensitive genes. This was based on the hypothesis that first, many genes are regulated on the transcriptional level, and second, specific transcription factor(s) as defined by the presence of their binding site(s) would be operative in the PS-sensitive gene set (or vice versa, ones with repressive function in the non-responsive set). In addition, target gene-micro RNA interactions were disclosed. As listed in Table 1, quantitative differences in NF- $\mathrm{BB}$ family member binding sites were identified. Taken together, we assume that NF- $\kappa B$ alone is not responsible for the early stages of inhibition, since activation of this pathway became apparent only after the first wave of activation, a time when differences in gene expression were already detectable. Alternatively, since gene expression is usually regulated through the interplay of different transcription factors binding to their promoters, the inhibition of NF- $\mathrm{KB}$ could in certain genes become compensated through the enhanced activity of other transcription factors. IL- 8 could be an example of this scenario, as it contains NF- $\mathrm{BB}, \mathrm{AP}-1$ (a target of JNK) and NF-IL6 binding sites; here, the loss of NF-kB activity might be compensated by enhanced JNK signaling, however, this remains speculative until experimentally proven. The next most significant hits were STAT5a and the target(s) of MIR23 A, B. Whereas the former supports, together with the regulation of IRF1, a role of PS in interferon signaling, the latter has been reported to suppress Apaf-1. Interestingly, Apaf- 1 is co-regulated together with the NF- $\kappa \mathrm{B}$ inhibitor IKIP (Hofer-Warbinek et al., 2004), so it might be speculated that MIR23 A, B could as well regulate indirectly NF$\kappa \mathrm{B}$. In the control pathway, besides other microRNAs, two transcriptional regulators/signaling pathways, namely $\mathrm{CHOP}$ and CREBP1/ATF2 are overrepresented; these findings reveal a complex interplay of different mechanism(s) warranting future studies on the level of the manifold PS constituents.

\section{DATA AVAILABILITY STATEMENT}

The original contributions presented in the study are publicly available. This data can be found here: https://www.ncbi.nlm.nih. gov/geo/, GSE178106.

\section{ETHICS STATEMENT}

The studies involving human participants were reviewed and approved by Ethics Commission of the Medical University of Vienna. Written informed consent to participate in this study was provided by the participants' legal guardian/next of kin.

\section{AUTHOR CONTRIBUTIONS}

$\mathrm{PN}, \mathrm{JZ}, \mathrm{IR}$, and AP performed the experiments and analyzed the results. JB and PU contributed scientifically to the design and supervised experiments. JR and RM designed the project, analyzed the data, and wrote the manuscript.

\section{FUNDING}

This research was funded by the Austrian Science Fund FWF (project no. P 31743-B30, to PU; and project no. P 34028, to JR).

\section{ACKNOWLEDGMENTS}

The authors acknowledge the Core Facilities of the Medical University of Vienna, a member of VLSI, for performing the microarray experiments.

\section{SUPPLEMENTARY MATERIAL}

The Supplementary Material for this article can be found online at: https://www.frontiersin.org/articles/10.3389/fphar.2021.802153/ full\#supplementary-material 


\section{REFERENCES}

Abdul-Sater, A. A., Edilova, M. I., Clouthier, D. L., Mbanwi, A., Kremmer, E., and Watts, T. H. (2017). The Signaling Adaptor TRAF1 Negatively Regulates Tolllike Receptor Signaling and This Underlies its Role in Rheumatic Disease. Nat. Immunol. 18, 26-35. doi:10.1038/ni.3618

Anrather, J., Racchumi, G., and Iadecola, C. (2005). cis-Acting, Element-Specific Transcriptional Activity of Differentially Phosphorylated Nuclear FactorKappa B. J. Biol. Chem. 280, 244-252. doi:10.1074/jbc.M409344200

Arunakumara, K. K. I. U., Walpola, B. C., Subasinghe, S., and Yoon, M. H. (2011). Pterocarpus Santalinus linn. F. (Rath Handun): A Review of its Botany, Uses, Phytochemistry and Pharmacology. J. Korean Soc. Appl. Biol. Chem. 54, 495-500. doi:10.3839/jksabc.2011.076

Bazan, J. F., Bacon, K. B., Hardiman, G., Wang, W., Soo, K., Rossi, D., et al. (1997). A New Class of Membrane-Bound Chemokine with a CX3C Motif. Nature 385, 640-644. doi:10.1038/385640a0

Birbach, A., Gold, P., Binder, B. R., Hofer, E., De Martin, R., and Schmid, J. A. (2002). Signaling Molecules of the NF-Kappa B Pathway Shuttle Constitutively between Cytoplasm and Nucleus. J. Biol. Chem. 277, 10842-10851. doi:10.1074/ jbc.M112475200

Bonta, P. I., Van Tiel, C. M., Vos, M., Pols, T. W. H., Van Thienen, J. V., Ferreira, V., et al. (2006). Nuclear Receptors Nur77, Nurr1, and NOR-1 Expressed in Atherosclerotic Lesion Macrophages Reduce Lipid Loading and Inflammatory Responses. Atvb 26, 2288. doi:10.1161/01.ATV.0000238346.84458.5d

Bulle, S., Reddy, V. D., Padmavathi, P., Maturu, P., and N Ch, V. (2016a). Modulatory Role of Pterocarpus Santalinus against Alcohol-Induced Liver Oxidative/nitrosative Damage in Rats. Biomed. Pharmacother. 83, 1057-1063. doi:10.1016/j.biopha.2016.08.031

Bulle, S., Reddyvari, H., Nallanchakravarthula, V., and Vaddi, D. R. (2016b). Therapeutic Potential of Pterocarpus Santalinus L.: An Update. Pharmacogn. Rev. 10, 43-49. doi:10.4103/0973-7847.176575

Camp, D., Davis, R. A., Campitelli, M., Ebdon, J., and Quinn, R. J. (2012). Drug-like Properties: Guiding Principles for the Design of Natural Product Libraries. J. Nat. Prod. 75, 72-81. doi:10.1021/np200687v

Carballo, E., Lai, W. S., and Blackshear, P. J. (2000). Evidence that Tristetraprolin Is a Physiological Regulator of Granulocyte-Macrophage colony-stimulating Factor Messenger RNA Deadenylation and Stability. Blood 95, 1891-1899. doi:10.1182/blood.v95.6.1891

Chen, L., Deng, H., Cui, H., Fang, J., Zuo, Z., Deng, J., et al. (2018). Inflammatory Responses and Inflammation-Associated Diseases in Organs. Oncotarget 9, 7204-7218. doi:10.18632/oncotarget.23208

Cho, J. Y., Park, J., Kim, P. S., Yoo, E. S., Baik, K. U., and Park, M. H. (2001). Savinin, a Lignan from Pterocarpus Santalinus Inhibits Tumor Necrosis FactorAlpha Production and T Cell Proliferation. Biol. Pharm. Bull. 24, 167-171. doi:10.1248/bpb.24.167

Cooper, J. T., Stroka, D. M., Brostjan, C., Palmetshofer, A., Bach, F. H., and Ferran, C. (1996). A20 Blocks Endothelial Cell Activation through a NF-kappaBdependent Mechanism. J. Biol. Chem. 271, 18068-18073. doi:10.1074/ jbc.271.30.18068

Dahat, Y., Saha, P., Mathew, J. T., Chaudhary, S. K., Srivastava, A. K., and Kumar, D. (2021). Traditional Uses, Phytochemistry and Pharmacological Attributes of Pterocarpus Santalinus and Future Directions: A Review. J. Ethnopharmacol. 276, 114127. doi:10.1016/j.jep.2021.114127

De Martin, R., Hoeth, M., Hofer-Warbinek, R., and Schmid, J. A. (2000). The Transcription Factor NF-Kappa B and the Regulation of Vascular Cell Function. Arterioscler. Thromb. Vasc. Biol. 20, E83-E88. doi:10.1161/ 01.atv.20.11.e83

Gilchrist, M., Thorsson, V., Li, B., Rust, A. G., Korb, M., Roach, J. C., et al. (2006). Systems Biology Approaches Identify ATF3 as a Negative Regulator of Toll-like Receptor 4. Nature 441, 173-178. doi:10.1038/NATURE04768

Guo, S., Messmer-Blust, A. F., Wu, J., Song, X., Philbrick, M. J., Shie, J. L., et al. (2014). Role of A20 in cIAP-2 protection against Tumor Necrosis Factor a (TNF- $\alpha$ )-Mediated Apoptosis in Endothelial Cells. Int. J. Mol. Sci. 15, 3816-3833. doi:10.3390/ijms15033816

Hofer-Warbinek, R., Schmid, J. A., Mayer, H., Winsauer, G., Orel, L., Mueller, B., et al. (2004). A Highly Conserved Proapoptotic Gene, IKIP, Located Next to the
APAF1 Gene Locus, Is Regulated by P53. Cel. Death Differ. 11, 1317-1325. doi:10.1038/sj.cdd.4401502

Hoffmann, A., Levchenko, A., Scott, M. L., and Baltimore, D. (2002). The IkappaBNF-kappaB Signaling Module: Temporal Control and Selective Gene Activation. Science 298, 1241-1245. doi:10.1126/science.1071914

Jaffe, E. A., Nachman, R. L., Becker, C. G., and Minick, C. R. (1973). Culture of Human Endothelial Cells Derived from Umbilical Veins. Identification by Morphologic and Immunologic Criteria. J. Clin. Invest. 52, 2745-2756. doi:10.1172/JCI107470

Jiang, Y., Feng, Y.-P., Tang, L.-X., Yan, Y.-L., and Bai, J.-W. (2019). The Protective Role of NR4A3 in Acute Myocardial Infarction by Suppressing Inflammatory Responses via JAK2-STAT3/NF-kB Pathway. Biochem. Biophys. Res. Commun. 517, 697-702. doi:10.1016/j.bbrc.2019.07.116

Jung, D. H., Kim, K. H., Byeon, H. E., Park, H. J., Park, B., Rhee, D. K., et al. (2015). Involvement of ATF3 in the Negative Regulation of iNOS Expression and NO Production in Activated Macrophages. Immunol. Res. 62, 35-45. doi:10.1007/ s12026-015-8633-5

Kaitu'u-Lino, T. J., Brownfoot, F. C., Hastie, R., Chand, A., Cannon, P., Deo, M., et al. (2017). Activating Transcription Factor 3 Is Reduced in Preeclamptic Placentas and Negatively Regulates sFlt-1 (Soluble Fms-Like Tyrosine Kinase 1), Soluble Endoglin, and Proinflammatory Cytokines in Placenta. Hypertension 70, 1014-1024. doi:10.1161/HYPERTENSIONAHA.117.09548

Kaminska, B. (2005). MAPK Signalling Pathways as Molecular Targets for Antiinflammatory Therapy-Ffrom Molecular Mechanisms to Therapeutic Benefits. Biochim. Biophys. Acta 1754, 253-262. doi:10.1016/j.bbapap.2005.08.017

Kerr, L. D., Inoue, J., Davis, N., Link, E., Baeuerle, P. A., Bose, H. R., et al. (1991). The Rel-Associated Pp40 Protein Prevents DNA Binding of Rel and NF-Kappa B: Relationship with I Kappa B Beta and Regulation by Phosphorylation. Genes Dev. 5, 1464-1476. doi:10.1101/gad.5.8.1464

Kim, Y. S., Ahn, Y., Hong, M. H., Joo, S. Y., Kim, K. H., Sohn, I. S., et al. (2007). Curcumin Attenuates Inflammatory Responses of TNF-Alpha-Stimulated Human Endothelial Cells. J. Cardiovasc. Pharmacol. 50, 41-49. doi:10.1097/ FJC.0b013e31805559b9

Kovanen, P. E., Rosenwald, A., Fu, J., Hurt, E. M., Lam, L. T., Giltnane, J. M., et al. (2003). Analysis of Gamma C-Family Cytokine Target Genes. Identification of Dual-Specificity Phosphatase 5 (DUSP5) as a Regulator of Mitogen-Activated Protein Kinase Activity in Interleukin-2 Signaling. J. Biol. Chem. 278, 5205-5213. doi:10.1074/jbc.M209015200

Kratz, J. M., Mair, C. E., Oettl, S. K., Saxena, P., Scheel, O., Schuster, D., et al. (2016). hERG Channel Blocking Ipecac Alkaloids Identified by Combined In Silico - In Vitro Screening. Planta Med. 82, 1009-1015. doi:10.1055/s-0042-105572

Kumar, D. (2011). Anti-inflammatory, Analgesic, and Antioxidant Activities of Methanolic wood Extract of Pterocarpus Santalinus L. J. Pharmacol. Pharmacother. 2, 200-202. doi:10.4103/0976-500X.83293

Kwon, J. W., Kwon, H. K., Shin, H. J., Choi, Y. M., Anwar, M. A., and Choi, S. (2015). Activating Transcription Factor 3 Represses Inflammatory Responses by Binding to the P65 Subunit of NF-kB. Sci. Rep. 5, 14470. doi:10.1038/ SREP14470

Lai, W. S., Carballo, E., Strum, J. R., Kennington, E. A., Phillips, R. S., and Blackshear, P. J. (1999). Evidence that Tristetraprolin Binds to AU-Rich Elements and Promotes the Deadenylation and Destabilization of Tumor Necrosis Factor Alpha mRNA. Mol. Cel. Biol. 19, 4311-4323. doi:10.1128/ mcb.19.6.4311

Lammel, C., Zwirchmayr, J., Seigner, J., Rollinger, J. M., and de Martin, R. (2020). Peucedanum Ostruthium Inhibits E-Selectin and VCAM-1 Expression in Endothelial Cells through Interference with NF- $\mathrm{KB}$ Signaling. Biomolecules 10, 1215. doi:10.3390/biom10091215

Livak, K. J., and Schmittgen, T. D. (2001). Analysis of Relative Gene Expression Data Using Real-Time Quantitative PCR and the $2-\Delta \Delta$ CT Method. Methods 25, 402-408. doi:10.1006/meth.2001.1262

Mayer, H., Bilban, M., Kurtev, V., Gruber, F., Wagner, O., Binder, B. R., et al. (2004). Deciphering Regulatory Patterns of Inflammatory Gene Expression from Interleukin-1-Stimulated Human Endothelial Cells. Arterioscler. Thromb. Vasc. Biol. 24, 1192-1198. doi:10.1161/01.ATV.0000131263.06296.77

Mercurio, F., Zhu, H., Murray, B. W., Shevchenko, A., Bennett, B. L., Li, J., et al. (1997). IKK-1 and IKK-2: Cytokine-Activated IkappaB Kinases Essential for NF-kappaB Activation. Science 278, 860-866. doi:10.1126/science.278.5339.860 
Miyamoto, M., Fujita, T., Kimura, Y., Maruyama, M., Harada, H., Sudo, Y., et al. (1988). Regulated Expression of a Gene Encoding a Nuclear Factor, IRF-1, that Specifically Binds to IFN-Beta Gene Regulatory Elements. Cell 54, 903-913. doi:10.1016/S0092-8674(88)91307-4

Murphy, E., and Crean, D. (2015). Molecular Interactions between NR4A Orphan Nuclear Receptors and NF- $\mathrm{kB}$ Are Required for Appropriate Inflammatory Responses and Immune Cell Homeostasis. Biomolecules 5, 1302-1318. doi:10.3390/biom5031302

Mussbacher, M., Salzmann, M., Brostjan, C., Hoesel, B., Schoergenhofer, C., Datler, H., et al. (2019). Cell Type-Specific Roles of NF- $\mathrm{BB}$ Linking Inflammation and Thrombosis. Front. Immunol. 10, 85. doi:10.3389/fimmu.2019.00085

Navada, K. K., and Vittal, R. R. (2014). Ethnomedicinal Value of Pterocarpus Santalinus (Linn. f.), a Fabaceae Member. Orient. Pharm. Exp. Med. 14, 313-317. doi:10.1007/s13596-014-0168-0

Neish, A. S., Read, M. A., Thanos, D., Pine, R., Maniatis, T., and Collins, T. (1995). Endothelial Interferon Regulatory Factor 1 Cooperates with NF-Kappa B as a Transcriptional Activator of Vascular Cell Adhesion Molecule 1. Mol. Cel. Biol. 15, 2558-2569. doi:10.1128/mcb.15.5.2558

Perkins, N. D. (2006). Post-translational Modifications Regulating the Activity and Function of the Nuclear Factor Kappa B Pathway. Oncogene 25, 6717-6730. doi:10.1038/sj.onc.1209937

Popichak, K. A., Hammond, S. L., Moreno, J. A., Afzali, M. F., Backos, D. S., Slayden, R. D., et al. (2018). Compensatory Expression of Nur77 and Nurr1

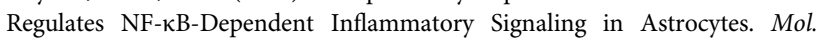
Pharmacol. 94, 1174-1186. doi:10.1124/MOL.118.112631

Quesenberry, P. J., and Gimbrone, M. A. (1980). Vascular Endothelium as a Regulator of Granulopoiesis: Production of colony-stimulating Activity by Cultured Human Endothelial Cells. Blood 56, 1060-1067. doi:10.1182/ blood.v56.6.1060.bloodjournal566106010.1182/blood.v56.6.1060.1060

Rodríguez-Calvo, R., Tajes, M., and Vázquez-Carrera, M. (2017). The NR4A Subfamily of Nuclear Receptors: Potential New Therapeutic Targets for the Treatment of Inflammatory Diseases. Expert Opin. Ther. Targets 21, 291-304. doi:10.1080/14728222.2017.1279146

Schichl, Y. M., Resch, U., Hofer-Warbinek, R., and de Martin, R. (2009). Tristetraprolin Impairs NF-kappaB/p65 Nuclear Translocation. J. Biol. Chem. 284, 29571-29581. doi:10.1074/jbc.M109.031237

Seigner, J., Basilio, J., Resch, U., and de Martin, R. (2018). CD40L and TNF Both Activate the Classical NF- $\kappa B$ Pathway, Which Is Not Required for the CD40L Induced Alternative Pathway in Endothelial Cells. Biochem. Biophys. Res. Commun. 495, 1389-1394. doi:10.1016/j.bbrc.2017.11.160

Seigner, J., Junker-Samek, M., Plaza, A., D’Urso, G., Masullo, M., Piacente, S., et al. (2019). A Symphytum Officinale Root Extract Exerts Anti-inflammatory Properties by Affecting Two Distinct Steps of NF-kB Signaling. Front. Pharmacol. 10, 289. doi:10.3389/fphar.2019.00289

Sen, N., Paul, B. D., Gadalla, M. M., Mustafa, A. K., Sen, T., Xu, R., et al. (2012). Hydrogen Sulfide-Linked Sulfhydration of NF- $\kappa$ B Mediates Its Antiapoptotic Actions. Mol. Cel. 45, 13-24. doi:10.1016/ j.molcel.2011.10.021

Su, X., Li, S., Meng, M., Qian, W., Xie, W., Chen, D., et al. (2006). TNF ReceptorAssociated Factor-1 (TRAF1) Negatively Regulates Toll/IL-1 Receptor Domain-Containing Adaptor Inducing IFN- $\beta$ (TRIF)-mediated Signaling. Eur. J. Immunol. 36, 199-206. doi:10.1002/eji.200535415
Sughra, K., Birbach, A., de Martin, R., and Schmid, J. A. (2010). Interaction of the TNFR-Receptor Associated Factor TRAF1 with I-Kappa B Kinase-2 and TRAF2 Indicates a Regulatory Function for NF-Kappa B Signaling. PLoS One 5, e12683. doi:10.1371/journal.pone.0012683

Thair, S. A., Topchiy, E., Boyd, J. H., Cirstea, M., Wang, C., Nakada, T. A., et al. (2016). TNFAIP2 Inhibits Early TNFa-Induced NF-x03BA;B Signaling and Decreases Survival in Septic Shock Patients. J. Innate Immun. 8, 57-66. doi:10.1159/000437330

Wang, L., Deng, S., Lu, Y., Zhang, Y., Yang, L., Guan, Y., et al. (2012). Increased Inflammation and Brain Injury after Transient Focal Cerebral Ischemia in Activating Transcription Factor 3 Knockout Mice. Neuroscience 220, 100-108. doi:10.1016/J.NEUROSCIENCE.2012.06.010

Winsauer, G., and de Martin, R. (2007). Resolution of Inflammation: Intracellular Feedback Loops in the Endothelium. Thromb. Haemost. 97, 364-369. doi:10.1160/TH06-08-0473

Winsauer, G., Resch, U., Hofer-Warbinek, R., Schichl, Y. M., and de Martin, R. (2008). XIAP Regulates Bi-phasic NF-kappaB Induction Involving Physical Interaction and Ubiquitination of MEKK2. Cell. Signal. 20, 2107-2112. doi:10.1016/j.cellsig.2008.08.004

Wu, S.-F., Chang, F.-R., Wang, S.-Y., Hwang, T.-L., Lee, C.-L., Chen, S.-L., et al. (2011). Anti-inflammatory and Cytotoxic Neoflavonoids and Benzofurans from Pterocarpus Santalinus. J. Nat. Prod. 74, 989-996. doi:10.1021/np100871g

You, B., Jiang, Y.-Y., Chen, S., Yan, G., and Sun, J. (2009). The Orphan Nuclear Receptor Nur77 Suppresses Endothelial Cell Activation Through Induction of IкBa Expression. Circ. Res. 104, 742-749. doi:10.1161/ CIRCRESAHA.108.192286

Yu, P. J., Ci, W., Wang, G. F., Zhang, J. Y., Wu, S. Y., Xu, W., et al. (2011). Praeruptorin A Inhibits Lipopolysaccharide-Induced Inflammatory Response in Murine Macrophages through Inhibition of NF- $\kappa \mathrm{B}$ Pathway Activation. Phytother Res. 25, 550-556. doi:10.1002/ptr.3295

Zhang, W. J., Wojta, J., and Binder, B. R. (1997). Notoginsenoside R1 Counteracts Endotoxin-Induced Activation of Endothelial Cells In Vitro and EndotoxinInduced Lethality in Mice In Vivo. Arterioscler. Thromb. Vasc. Biol. 17, 465-474. doi:10.1161/01.ATV.17.3.465

Conflict of Interest: The authors declare that the research was conducted in the absence of any commercial or financial relationships that could be construed as a potential conflict of interest.

Publisher's Note: All claims expressed in this article are solely those of the authors and do not necessarily represent those of their affiliated organizations, or those of the publisher, the editors and the reviewers. Any product that may be evaluated in this article, or claim that may be made by its manufacturer, is not guaranteed or endorsed by the publisher.

Copyright (c) 2022 Natalia, Zwirchmayr, Rudžionyte, Pulsinger, Breuss, Uhrin, Rollinger and de Martin. This is an open-access article distributed under the terms of the Creative Commons Attribution License (CC BY). The use, distribution or reproduction in other forums is permitted, provided the original author(s) and the copyright owner(s) are credited and that the original publication in this journal is cited, in accordance with accepted academic practice. No use, distribution or reproduction is permitted which does not comply with these terms. 